Menoufia J. Food \& Dairy Sci., Vol. 6 Dec. (2021): 35-50 https://mjfds.journals.ekb.eg

\title{
EFFECT OF EXTRACTION MEDIUM AND ACID TYPE ON THE PHYSIO -CHEMICAL PROPERTIES OF ORANGE PEELS ISOLATED PECTIN
}

\author{
Hager A. Abd- Elazize, E. H. Rahma, T.A. El-Adawy and A. E. Elbltagy \\ Food Science and Technology Department, Faculty of Agriculture, Menoufia University, \\ Shibin El-Kom, Egypt
}

Received: Oct. 17, 2021

Accepted: Dec. 5, 2021

\begin{abstract}
Pectin is found to be widely used as additives in food, pharmaceutical and cosmetic industries. This study was carried out using orange peel as raw material to produce pectin and studied the effect of extraction medium type and concentrations on the Physio -chemical properties of orange peels isolated pectin and the different factors affecting pectin extraction and characterization using orange peel as raw material. Citric acid was higher in pectin yield $54.80 \%$ and $23.44 \%$ using citric and $\mathrm{Hcl}$ respectively. The optimum acid concentrations for pectin extraction was found to be $1 \mathrm{~N}$ and $0.3 \mathrm{~N}$ for citric and $\mathrm{Hcl}$ respectively and the suitable time and temperature for extraction was $60 \mathrm{~min}$ and $90^{\circ} \mathrm{C}$ for both acids used. There was a significant difference in isolated pectin physiochemical properties according to the acid used for pectin extraction. The contents of ash and a moisture in isolated pectins were lower for citric acid compared to $\mathrm{Hcl}$ treatment. Temperature had a significant effect on some Physio -chemical properties such as equivalent weight, methoxyl content and total anhydrouronic acid but degree of esterification wasn't significantly affected. Pectin's obtained in this study were characterized as high methoxyl pectin (HMP) since the DE was higher than $\mathbf{5 0} \%$. Total anhydrouronic acid for both acid was low than $65 \%$ so the pectin isolated needs more purification. In general results proved that orange citric acid prepared pectin has better physio -chemical properties which are a good indications in pectin quality evaluation.
\end{abstract}

Key words: Pectin, Physio -chemical, Degree of esterification, Total Anhydrouronic acid, Equivalent Weight, Methoxyl Content.

\section{INTRODUCTION}

The term pectin was first described and isolated by a French scientist named Henry Braconnot in 1825 . Pectin is primarily made up of D-galacturonic acid joined by $\alpha-(1-4)$ glycosidic linkages (Vauquelin, 1790; Van Buren, 1991). Pectins are a family of complex polysaccharides that contain 1,4-linked $\alpha$-Dgalactosyluronic residues (Sharma et al., 2006). The degree of esterification (DE) is an important parameter for the definition of pectin applications and it is defined as the percentage of carboxyl groups esterified present in the structure of pectin. DE is often used to classify the different types of pectins (Cristina et al., 2020). Pectin is widely used in the food industry as a thickener, emulsifier, texturizer and stabilizer. Pectin is usually used in jams and jellies as a gelling agent and also used for fruit preparations, fruit drink concentrates, fruit juice, desserts, and fermented dairy products (Tsoga el al., 2004).

\section{MATERIALS AND METHODS Materials}

Plant materials:

Orange fruit was purchased from the local market at Shibin El-Kom City, 
Hager A. A. Rahma, et al.,

Menoufia Governorate, Egypt during the winter season of 2019.

\section{Reagents and chemicals:}

Hydrochloric acid, citric acid, absolute ethanol, sodium hydroxide sodium chloride, phenol red, boric acid sulfuric acid and perchloric acid were obtained from El-Naser pharmaceutical Chemicals, Ameriea, Cairo, Egypt.

\section{Methods:}

Technological methods:

Preparation of plant materials:
The orange fruit was first washed several times with tap water and rinsed several times with distilled water. They were cut into small pieces. The juice was extracted by juice extractor, then filtered by hands through two-layer cheese cloths The remaining peels were washed thoroughly using tap water to remove soluble sugars then dried at $60^{\circ} \mathrm{C}$ for 24 hours in a drier followed by grinding into powder using an electric blender (Fig 1). The peel powder was packed in low density polyethylene bags and stored at the freezer until use for pectin extraction.

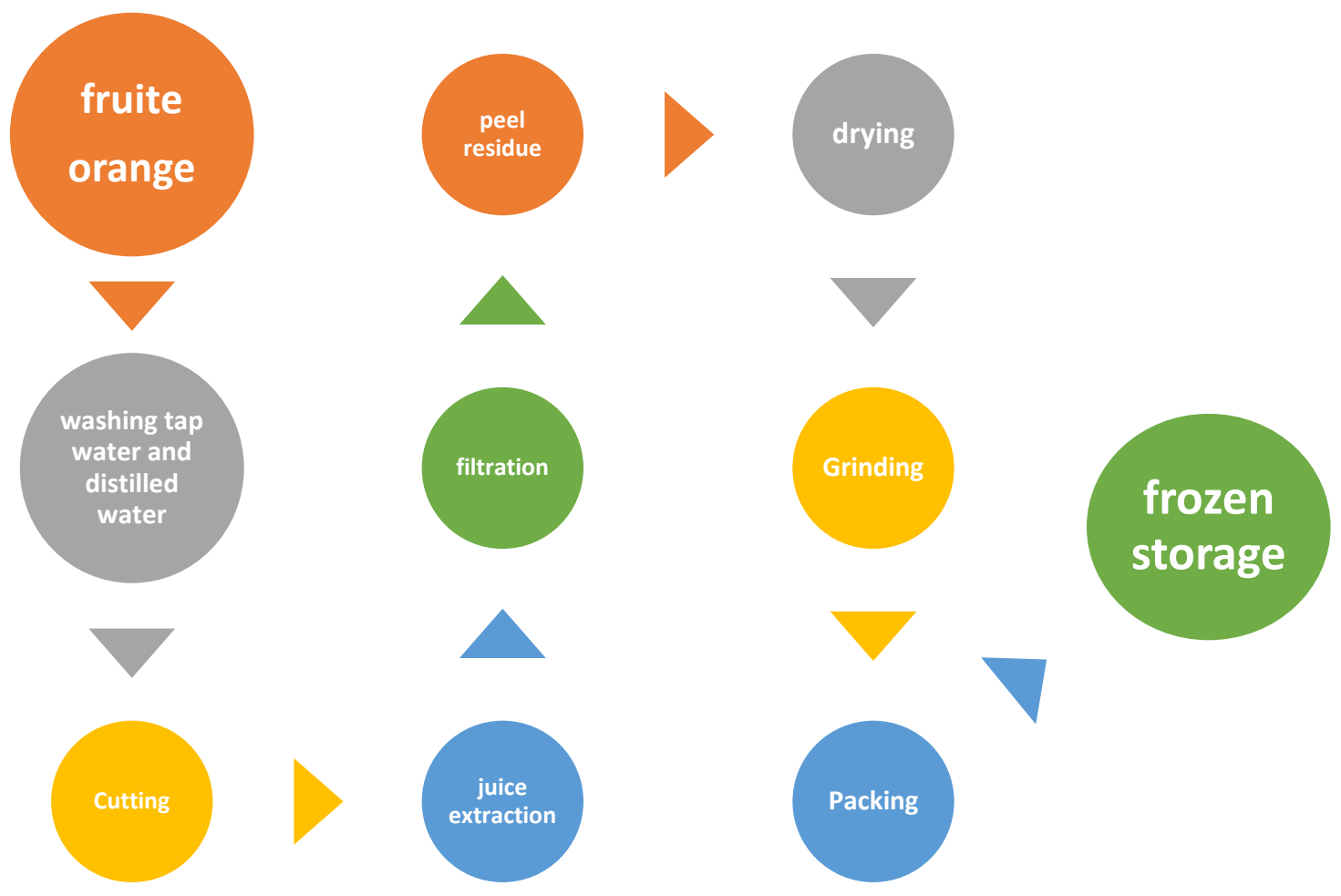

Fig (1): Flow sheet for orange peel preparation (Raw materials). 


\section{Extraction of pectin}

Extraction of pectin in this study was conducted by using the conventional acid extraction method. The procedure of Altafu. et al. (2014) was followed for pectin extraction with several modifications. Method for extraction of pectin consisted of adding $250 \mathrm{ml}$ of $\mathrm{Hcl}$ $0.3 \mathrm{~N}$ or citric acid $1 \mathrm{~N}$ to $20 \mathrm{~g}$ orange peel powder in a beaker and then heating the mixture to $70^{\circ} \mathrm{C}, 80^{\circ} \mathrm{C}$ and $90^{\circ} \mathrm{C}$ for 30,45 and 60 mines respectively, in a hot water bath. Then the solution was filtered through muslin cloth. The pectin extract obtained from the different extraction treatments, after cooling to the room temperature, was precipitated with $96 \%$ ethanol (alcoholic precipitation) and kept for an hour at room temperature for complete pectin precipitation. Filtration was done again to the separation of coagulated pectin then washed with $75 \%$ ethanol $(v / v)$ and absolute ethanol to remove the soluble impurities. The coagulated pectin was then kept for drying in the oven at $50^{\circ} \mathrm{C}$ for 24 hours. After drying, the pectin was ground (Fig. 2). The dried powder pectin obtained from both peels was packed separately in food grade polythene bags and stored in a cool dry place until used for further analysis.

\section{Physico -chemical analysis of pectin}

The extracted pectin was analysed for yield, moisture, ash, protein, equivalent weight, methoxyle content, total anhydrouronic acid and degree of esterification according to the following methods

\section{Pectin Yield}

Pectin yield was calculated as follows:

pectin $\%=$

$\frac{\text { Weight }(\mathrm{g}) \text { of dried pectin }}{\text { Weight }(\text { g)dried orang peel powder }} \times 100$

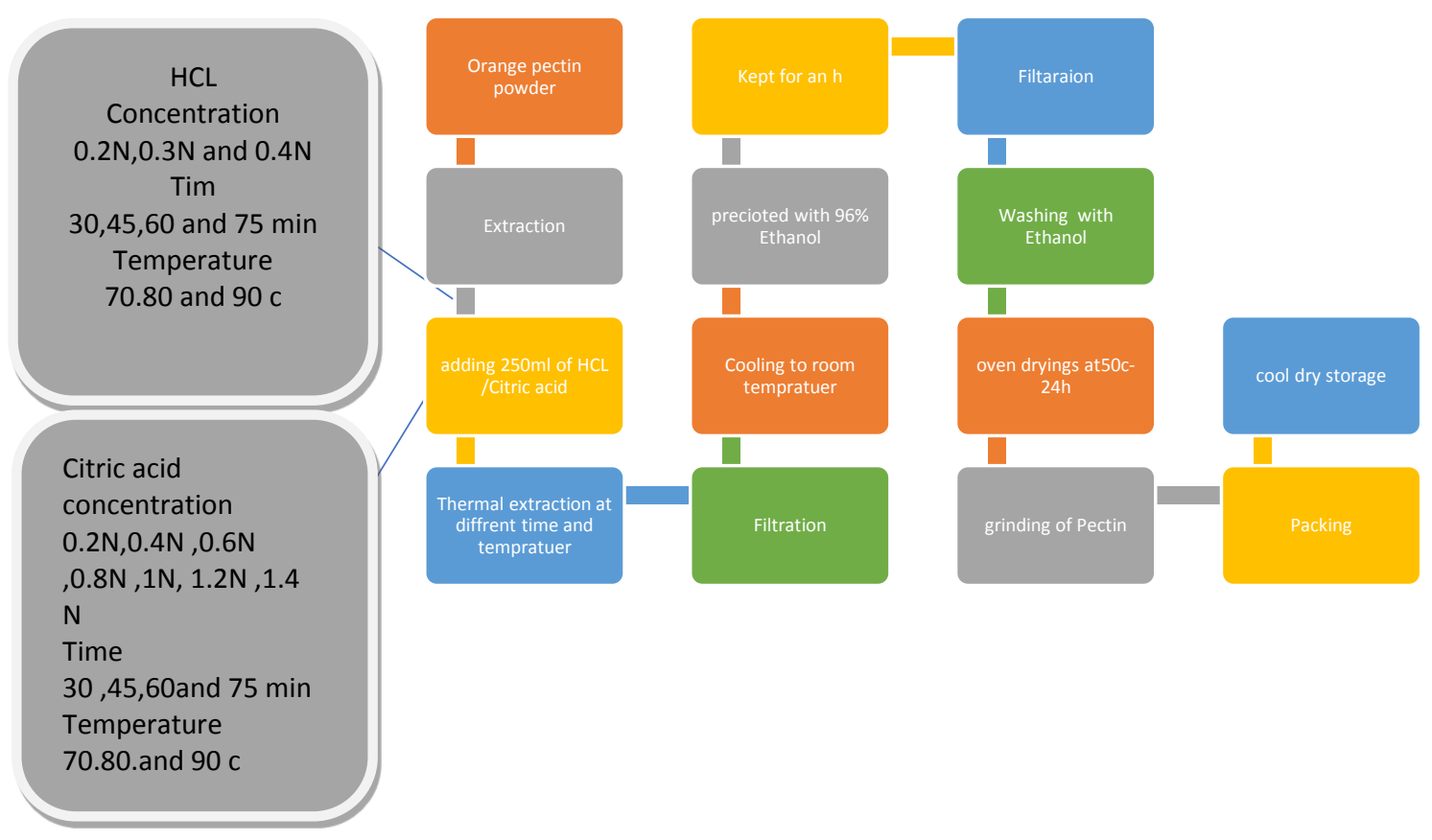

Fig (2): Extraction procedures for pectin from orange peels powder. 
Hager A. A. Rahma, et al.,

\section{Determination of Moisture}

Moisture content of pectin was determined by the method of AOAC (1995). According to the following equation

moisture content $\%=\frac{W-W 1}{W} X 100$

W: weight of the fresh sample

W1: weight of the dried sample

\section{Determination of ash content}

Ash content of pectin samples was determined by Ranganna's method (1995). The sample was ignited slowly, then heated for 3-4 $\mathrm{hr}$ at $600 \stackrel{\circ}{\circ}$, then cooled the crucible to room temperature in a desiccator and weighed properly. The process will be continued until constant weight and final weight was recorded. The ash content was calculated from the following equation

Ash content $\%=\frac{W 2-W 1}{W} \times 100$

Where, W2 - Final weight of dish and ash, W1- Weight of dish, W- Weight of pectin sample.

\section{Determination of protein}

The determination of pectin protein content was done with the semi micro Kjeldahl distillation according to the method of AOAC (1999). The factor of 6.25 was used for protein calculation.

\section{Determination of equivalent weight (EW)}

Equivalent weight was determined by Ranganna's method (1995). A 0.5 g pectin sample was taken in a $250 \mathrm{ml}$ conical flask and $5 \mathrm{ml}$ ethanol $95 \%$ was added. 1 $\mathrm{g}$ of sodium chloride and $100 \mathrm{ml}$ of distilled water were added. Finally, 6 drops of phenol red indicator was added. The pectin substances were stirred rapidly to dissolve, then titrated slowly with $0.1 \mathrm{~N} \mathrm{NaOH}$. Titration point was indicated by purple colour. This neutralized solution was kept for the determination of methoxyl content.

Equivalent weight was calculated by the following formula:

$$
\begin{aligned}
& \text { Equivalent weight } \\
& =\frac{\text { Weight of sample X1000 }}{\text { ml of alkali X normality of alkali }}
\end{aligned}
$$

\section{Determination of pectin Methoxyl Content (MeO)}

Determination of $\mathrm{MeO}$ was done by using the Ranganna's method (1995). The neutral solution collected from determination of equivalent weight; $25 \mathrm{ml}$ of sodium hydroxide $(0.25 \mathrm{~N})$ was added. The mixed solution was stirred thoroughly and kept at room temperature for $30 \mathrm{~min}$. and then $25 \mathrm{ml}$ of $0.25 \mathrm{~N}$ hydrochloric acid was added and titrated against $0.1 \mathrm{~N} \mathrm{NaOH}$ to the same end point as before. Methoxyl content was calculated by the following formula:

Methoxyl Content $\%$ $=\frac{m l \text { of alkali } X \text { normality of alkali X31 }}{\text { Weight of sample }}$

Where 31 is the molecular weight of the methoxyl group.

\section{Determination of Total Anhydrouronic Acid Content (AUA)}

Total AUA of pectin was obtained by the following formula (mohamed \& Hasan, 1995):

$A U A \% \frac{176 X 0.1 Z X 100}{W X 1000}+\frac{176 \times 0.1 Y \times 100}{W X 1000}$

Where molecular unit of AUA (1 unit) $=176 \mathrm{~g}$ Where, $z=\mathrm{ml}$ (titre) of $\mathrm{NaOH}$ from equivalent weight determination

$y=\mathrm{ml}$ (titre) of $\mathrm{NaOH}$ from methoxyl content determination

$\mathbf{w}=$ weight of sample (gm) 


\section{Determination of pectin degree of esterification (DE)}

The DE of pectin was measured on the basis of methoxyl and AUA content (Owens et al., 1952) and calculated by flowing the formula:

$\% D E=\frac{176 \times \text { MEO }}{31 X A U A} X 100$

Where molecular unit of AUA (1 unit) $=176 \mathrm{~g}$ Where 31 is the molecular weight of the methoxyl group.

\section{Statistical analysis}

Statistical analysis of pectin extraction factors and properties were conducted according to Snedecor and Cochran (1994). Results are expressed as the mean value \pm SD of three separate determinations. The results were analysed using one-way analysis of variance for all experiments. The least significant difference (LSD) was used for comparison among means, considering significance at $0.05 \%$ level, using Costat version 6.311 (Copyright 1998-2005, CoHort software).

\section{RESULT AND DISCUSSION}

\section{Extraction and preparation of pectin from orange peel}

Washed dried orange peel were the raw material to extract and prepare pectin. Factors effecting pectin yield i.e acid concentration, temperature extraction and time of extraction were performed to determine the optimum conditions required to give the highest pectin yield. In this regard, two acids were used separately, citric acid as an organic acid and HCL as strong mineral acid. The obtained results will be discussed according to the following titles.

\section{Pectin extraction from orange peels using Hydrochloric acid and citric acid}

\section{Effect of acid concentration}

Data in (Table 1) represent the effect of hydrochloric acid and citric acid concentrations on pectin yield. According to the hydrochloric acid, three different concentrations were used to extract the orange peel pectin. The concentrations of hydrochloric acid were $0.2 \mathrm{~N}, 0.3 \mathrm{~N}$ and $0.4 \mathrm{~N}$ respectively. The maximum yield using hydrochloric acid was $23,26 \%$ attained at $0.3 \mathrm{~N}$ of hydrochloric acid. However the other two concentrations used 0,2 and 0,4 were lower in pectin yield $20,43 \%$ and $20,93 \%$ respectively. The pectin yield decreased when the hydrochloric acid concentration increased more than $0.3 \mathrm{~N}$ because of strong acid solution could lead to smaller pectin particles owing to partial acid hydrolysis. Consequently, pectin solubility would increase to the point that not precipitate was formed by the addition of alcohol (Kalapathy and proctor,2001). While citric acid was used in the range of 0.2 to $1.4 \mathrm{~N}$ concentration. The extraction time and temperature were $60 \mathrm{~min}$ and $80^{\circ} \mathrm{C}$ respectively. There were a gradual increase in pectin yield as the concentration of acid increased. The maximum yield was obtained at $1 \mathrm{~N}$ of

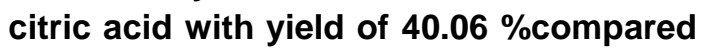
to $11.2 \%$ at $0.2 \mathrm{~N}$ and $30.52 \%$ at $1.4 \mathrm{~N}$ There was a gradual increase in pectin yield as the concentration of acid increased .Siti et al., (2020) reported that the yield of extracted pectin from honeydew peels using citric acid at $70^{\circ} \mathrm{C}$ for 30,45 and $60 \mathrm{~min}$ was $29.51 \%, 31.32 \%$ and $32.58 \%$ respectively. Devi et al., (2014) who had compared the pectin yield extracted from sweet lemon peels using two different types of acids (citric and nitric acid) and concluded that citric acid gave the highest percentage yield which agree with our finding. Based on The ANOVA results, citric acid and hydrochloric acid concentration had a significant effect on pectin yield. 
Hager A. A. Rahma, et al.,

\section{Effect of extraction time}

Table (2) showed that the pectin yield from orange peel using citric acid $1 \mathrm{~N}$ and hydrochloric acid $0.3 \mathrm{~N}$ at $80^{\circ} \mathrm{C}$ for different periods for extraction 30 to 75 min. The pectin yield increased with increasing the time of extraction reached $60 \mathrm{~min}$. However, extraction time when reaching $75 \mathrm{~min}$, the yield of pectin was decreased to the minimum $20.10 \%$ and $39.50 \%$ for hydrochloric acid and citric acid, respectively. This is because of thermal degradation of pectin which causes a decrease in the amount of pectin precepted by alcohol (Girma and Teshoma,2016). The ANOVA results showed that time had a significant effect on pectin yield and the best time of extraction was $60 \mathrm{~min}$ using $0.3 \mathrm{~N}$ hydrochloric acid and $90^{\circ} \mathrm{C}$ with significant difference $(P \leq 0.05)$ compared to the other times of extraction.

Table (1): Pectin yield extracted from orange peels by using different concentrations of citric acids and Hydrochloric acids at $80^{\circ} \mathrm{C}$ and $60 \mathrm{~min}$

\begin{tabular}{|c|c|c|}
\hline \multirow{2}{*}{ Concentration (N) } & \multicolumn{2}{|c|}{ Pectin yield (\%) } \\
\cline { 2 - 3 } & Citric acid & Hydrochloric acid \\
\hline 0.2 & $11.21^{\mathrm{h}} \pm 0.20$ & $20.3^{\mathrm{c}} \pm 0.3$ \\
\hline 0.3 & - & $23.26^{\mathrm{a}} \pm 0.20$ \\
\hline 0.4 & $16.11^{\mathrm{g}} \pm 0.14$ & $20.93^{\mathrm{b}} \pm 0.12$ \\
\hline 0.6 & $21.30^{\mathrm{f}} \pm 0.14$ & - \\
\hline 0.8 & $24.85^{\mathrm{e}} \pm 0.21$ & - \\
\hline 0.9 & $32.72^{\mathrm{c}} \pm 0.22$ & - \\
\hline 1.0 & $40.06^{\mathrm{a}} \pm 0.10$ & - \\
\hline 1.2 & $37.08^{\mathrm{b}} \pm 0.073$ & - \\
\hline 1.4 & $30.52^{\mathrm{d}} \pm 0.02$ & - \\
\hline LSD & 0.82 & 0.44 \\
\hline
\end{tabular}

Means in the same column with different letters are significantly difference $(p \leq 0.05)$.

Means \pm standard deviation of means of three determinations.

LSD: Least significant difference.

Table (2): Pectin yield extracted from orange peels as affected by different times using $0.3 \mathrm{~N}$ hydrochloric and Citric acid $1 \mathrm{~N}$ at $80^{\circ} \mathrm{C}$

\begin{tabular}{|c|c|c|}
\hline \multirow{2}{*}{ Extraction time (min) } & \multicolumn{2}{|c|}{ Pectin yield (\%) } \\
\cline { 2 - 3 } & Hydrochloric acid & Citric acid \\
\hline 30 & $21.5^{\mathrm{c}} \pm 0.1$ & $37.10^{\mathrm{d}} \pm 0.2$ \\
\hline 45 & $22.08^{\mathrm{b}} \pm 0.15$ & $38.61^{\mathrm{c}} \pm 0.3$ \\
\hline 60 & $23.6^{\mathrm{a}} \pm 0.14$ & $44.45^{\mathrm{a}} \pm 0.18$ \\
\hline 75 & $20.10^{\mathrm{d}} \pm 0.1$ & $39.50^{\mathrm{b}} \pm 0.15$ \\
\hline LSD & 0.10 & 0.17 \\
\hline
\end{tabular}

Means in the same column with different letters are significantly difference $(p \leq 0.05)$.

Means \pm standard deviation of means of three determinations.

LSD: Least significant difference. 


\section{Effect of temperature on pectin yield}

Table (3) showed that the effect of extracting temperature $\left(70-90^{\circ} \mathrm{C}\right)$ on pectin yield from orange peel using citric acid and hydrochloric acid time of extraction $60 \mathrm{~min}$. The ANOVA results showed that the temperature had a significant effect on pectin yield. The amount of pectin yield extracted from orange peel increased significantly with the increasing of extraction temperature from $70-90^{\circ} \mathrm{C}$ and time from $30 \mathrm{~min}$ to 75 min (Table 3). It is clear that $90^{\circ} \mathrm{C}$ and $60 \mathrm{~min}$ were optimum factors to give maximum yield of pectin $(54.80 \%)$. Girma and Worku, (2016) reported that increasing the extraction temperature led to an increase in the solubility of the extracted pectin in acid which is promoted in a high rate of extraction. From these results it be concluded that the optimum conditions for higher orange peel pectin yield using hydrochloric acid are $\mathrm{HCl}$ concentration $0.3 \mathrm{~N}$ for $60 \mathrm{~min}$ and temperature at $90^{\circ} \mathrm{C}$. The yield was $24.15 \%$ compared to citric acid optimum concentration $1 \mathrm{~N}$ which was $54.80 \%$ for orange peels extraction. In general, organic acids produce higher pectin yield than that of strong minerals acid due to the lower rate of pectin thermal degradation during extraction.

\section{Physicochemical characteristics of isolated pectin}

Physicochemical characteristics of orange peel pectin extracted by hydrochloric acid and Citric acid at different temperature

The physiochemical properties of orange peel pectin extracted by hydrochloric acid and citric acid at different temperature $\left(80^{\circ} \mathrm{C}\right.$ and $\left.90^{\circ} \mathrm{C}\right)$ are presented in Tables (4,5) and Fig (1-5) These characteristics include yield (\%), equivalent weight (g/ mol), methoxyl content, total Anhydrouronic acid (\%), degree of esterification (\%), moisture content (\%) ash content and protein content along with the market pectin sample for comparison. It is clear that the temperature of extraction has a significant $(P \leq 0.05)$ effect on most of the physicochemical properties of pectin extracted from orange peel using hydrochloric acid. The yield of extracted pectin using $\mathrm{HCl}$ was 23.55 and $24.15 \%$ at $80 \mathrm{c}^{\circ}$ and 90 respectively with a significant difference $(P \leq 0.05)$.

\section{Equivalent weight (g/ mol)}

According to Fig (3) and Tables $(4,5)$ the equivalent weight of pectin from orange peel using hydrochloric acid $0.3 \mathrm{~N}$ and citric acid 1N. According to hydrochloric acid the equivalent weight was found to be 1428.85 and $787.41 \mathrm{~g} /$ mol which was against $1364.6 \mathrm{~g} / \mathrm{mol}$ for commercial pectin. While citric acid, the equivalent weight of pectin was found to be 1496.01 and 1219.83 at 80 and $90^{\circ} \mathrm{c}$ respectively. The observed decrease in the equivalent weight could be due to thermal degredation of extracted pectin. Ramli and Asmawati (2011) claimed that the equivalent weight of the pectin varies in abroad range number since it depends on the method and nature of the fruit used for extraction. Pectin with high equivalent weight could have a higher gel forming effect when being added to food or pharmaceutical product. In addition to higher partial thermal degradation of pectin differences in the value of equivalent weight were being affected by the amount of free acid present in the pectin extract. Ramli and Asmawati (2011) reported that the equivalent weight of extracted pectin from lemon pomac during ripening was $1175 \pm 82,1632 \pm 137$ and 368 3 from premature, mature and over ripen stage respectively. The ANOVA tests showed that the temperature had a significant effect on the equivalent weight of pectin extracted by hydrochloric acid and citric acid. The 
Hager A. A. Rahma, et al.,

EW of pectin isolated at $80^{\circ} \mathrm{c}$ using hydrochloric acid was similar to $(P>0.05)$ the market sample. But $90^{\circ} \mathrm{c}$ extracted pectin showed the lowest value with significant differences with the other sample indicating the effect of extraction temperature on EW content of pectin.

Table (3): Pectin yield extracted from orange peels as affected by different temperatures using $0.3 \mathrm{~N}$ hydrochloric acid and $1 \mathrm{~N}$ Citric acid and at $60 \mathrm{~min}$

\begin{tabular}{|c|c|c|}
\hline \multirow{2}{*}{ Temperature $\left({ }^{\circ} \mathrm{c}\right)$} & \multicolumn{2}{|c|}{ Pectin yield $(\%)$} \\
\cline { 2 - 3 } & Hydrochloric acid & Citric acid \\
\hline 70 & $18.90^{\mathrm{c}} \pm 0.1$ & $39.91^{\mathrm{c}} \pm 0.15$ \\
\hline 80 & $23.65^{\mathrm{b}} \pm 0.15$ & $44.45^{\mathrm{b}} \pm 0.3$ \\
\hline 90 & $24.15^{\mathrm{a}} \pm 0.14$ & $54.80^{\mathrm{a}} \pm 0.18$ \\
\hline LSD & 0.10 & 0.17 \\
\hline
\end{tabular}

Means in the same column with different letters are significantly difference ( $p \leq 0.05)$.

Means \pm standard deviation of means of three determinations.

LSD: Least significant difference.

Table (4): Physicochemical characteristics of orange peel pectin extracted by hydrochloric acid at different temperature.

\begin{tabular}{|c|c|c|c|c|}
\hline \multirow{2}{*}{ Characteristics } & \multicolumn{4}{|c|}{ Pectin samples } \\
\cline { 2 - 5 } & Commercial & $800 \mathrm{C}$ & $900 \mathrm{C}$ & LSD \\
\hline Yield & - & 23.55 & 24.15 & \\
\hline Equivalent weight (g-mol) & $1364^{\mathrm{a}} \pm 57$ & $1428.85^{\mathrm{a}} \pm 41$ & $787.49^{\mathrm{b}} \pm 49$ & 134.6 \\
\hline Methoxyle content (\%) & $10.63^{\mathrm{a}} \pm 0.34$ & $5.52^{\mathrm{c}} \pm 0.19$ & $6.57^{\mathrm{b}} \pm 0.38$ & 0.33 \\
\hline Anhydrouronic acid \% ( AUA) & $74.60^{\mathrm{a}} \pm 2.4$ & $44.70^{\mathrm{c}} \pm 0.8$ & $61.96^{\mathrm{b}} \pm 0.6$ & 2.73 \\
\hline Degree of esterification\% (DE) & $89.37^{\mathrm{a}} \pm 0.4$ & $76.56^{\mathrm{b}} \pm 2.04$ & $76.18^{\mathrm{b}} \pm 3.2$ & 3.86 \\
\hline Moisture content (\%) & $9.56^{\mathrm{a}} \pm 0.15$ & $7.47^{\mathrm{c}} \pm 0.16$ & $8.93^{\mathrm{b}} \pm 0.55$ & 0.62 \\
\hline Ash content (\%) & $2.19^{\mathrm{c}} \pm 0.16$ & $5.40^{\mathrm{a}} \pm 0.22$ & $4.39^{\mathrm{b}} \pm 0.4$ & 0.44 \\
\hline Protein (\%) & $2.71^{\mathrm{c}} \pm 0.33$ & $6.40^{\mathrm{a}} \pm 0.09$ & $5.57^{\mathrm{b}} \pm 0.34$ & 0.33 \\
\hline
\end{tabular}

Means in the same row with different letters are significantly difference ( $p \leq 0.05)$.

Means \pm standard deviation of means of three determinations.

LSD: Least significant difference

Table (5): Physicochemical characteristics of orange peels pectin extracted by citric acid at different temperature.

\begin{tabular}{|c|c|c|c|c|}
\hline \multirow{2}{*}{ Characteristics } & \multicolumn{4}{|c|}{ Pectin samples } \\
\cline { 2 - 5 } & Commercial & $80^{\circ} \mathrm{C}$ & $90^{\circ} \mathrm{C}$ & LSD \\
\hline Yield & - & 44.43 & 54.8 & \\
\hline Equivalent weight (g-mol) & $1364^{\mathrm{ab}} \pm 57$ & $1489^{\mathrm{a}} \pm 77$ & $1219^{\mathrm{b}} \pm 29$ & 160.5 \\
\hline Methoxyle content (\%) & $10.63^{\mathrm{a}} \pm 0.34$ & $6.75^{\mathrm{c}} \pm 0.22$ & $7.88^{\mathrm{b}} \pm 0.24$ & 0.36 \\
\hline Anhydrouronic acid (\%) (AUA) & $74.60^{\mathrm{a}} \pm 2.4$ & $51.24^{\mathrm{c}} \pm 0.5$ & $60.65^{\mathrm{b}} \pm 1,1$ & 3.2 \\
\hline Degree of esterifaction (\%)(DE) & $89.37^{\mathrm{a}} \pm 0.4$ & $81.37^{\mathrm{b}} \pm 2.04$ & $82.10^{\mathrm{b}} \pm 3.2$ & 3 \\
\hline Moisture content (\%) & $9.56^{\mathrm{a}} \pm 0.15$ & $6.60^{\mathrm{c}} \pm 0.15$ & $8.63^{\mathrm{b}} \pm 032$ & 0.33 \\
\hline Ash content (\%) & $2.19^{\mathrm{b}} \pm 0.16$ & $4.03^{\mathrm{a}} \pm 0.27$ & $3.78^{\mathrm{a}} \pm 0.36$ & 0.76 \\
\hline Protein (\%) & $2.71^{\mathrm{c}} \pm 0.33$ & $7.30^{\mathrm{a}} \pm 0.0$ & $6.18^{\mathrm{b}} \pm 0.6$ & 0.71 \\
\hline
\end{tabular}

Means in the same row with different letters are significantly difference $(p \leq 0.05)$.

Means \pm standard deviation of means of three determinations.

LSD: Least significant difference. 


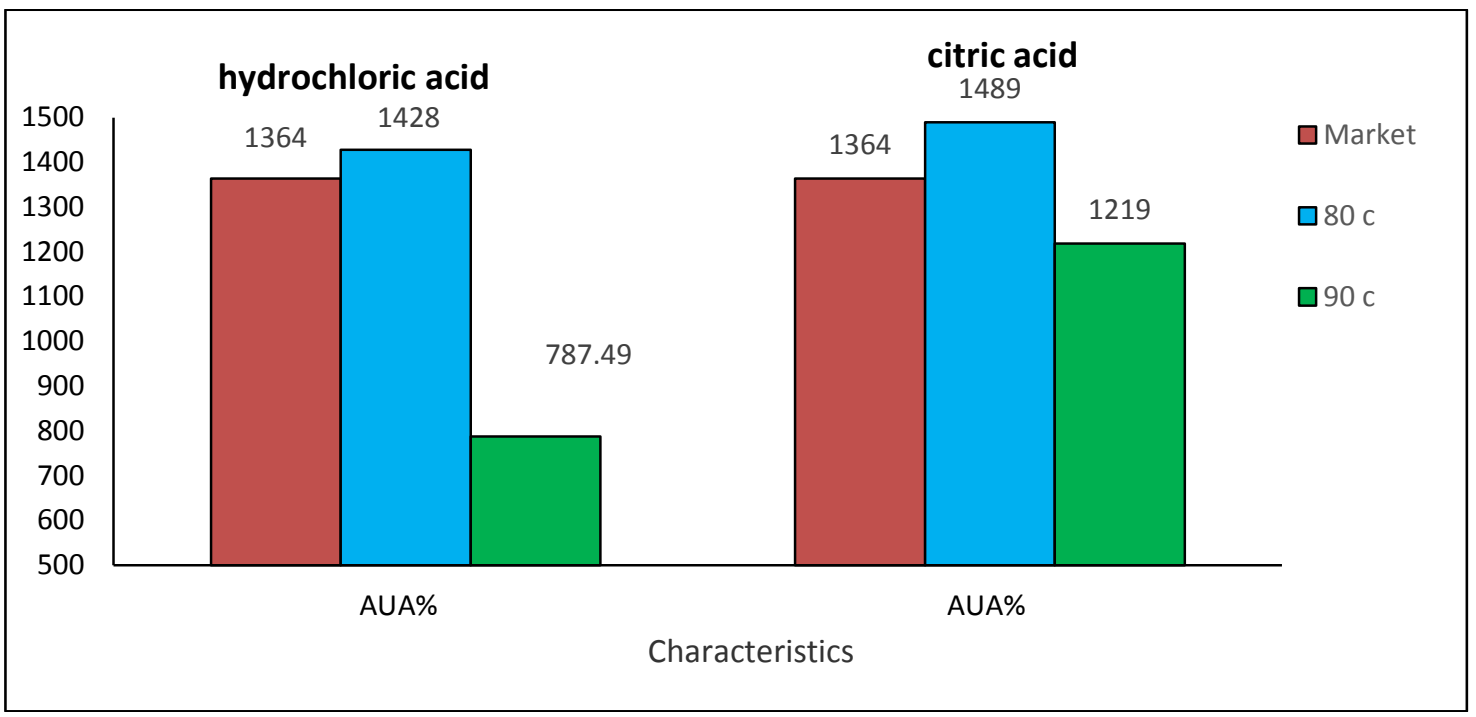

Figure (3): Equivalent weight of orange peel pectin extracted by hydrochloric acid and citric acid at different temperature

\section{Methoxyle content (MeO)}

Methoxyle content is an important factor in controlling the setting time of pectin and ability of the pectin to form gel (Constenla and lozano, 2003). According to Tables $(4,5)$ and Fig (4) methoxyle content of pectin from orange peel using hydrochloric acid was found to be $5.52 \%$ and $6.57 \%$ for pectin extracted at $80^{\circ} \mathrm{c}$ and $90^{\circ} \mathrm{C}$ respectively which was against $10.63 \%$ for commercial pectin. While the methoxyle content of orange peels extracted pectin using citric acid was found to be $6.75 \%$ and $7.88 \%$ respectively Azad et al., (2014) reported that the methoxyle content of pectin from sweet lemon peel using citric acid and nitric acid was found to be $6.2 \%$ and $5.27 \%$ respectively. Devi et al., (2014) found the methoxyl content of pectin extracted from sweet lemon peel powder using citric and nitric acid was $6.2 \%$ and $5.27 \%$ respectively which was very close to our value of $6.75 \%$ at $80 \mathrm{c}$. The following value for methoxyle content was reported in the literature for different pectin mango peels $(7.33 \%)$, banana $(7.03 \%)$, lime $(9.92 \%)$, passion (8.81-9.61\%) dragon fruit pectin $2.98-4.34 \%$. Madhev and
Pushpalatha, (2002). Methoxyle content of market sample was higher than $80^{\circ} \mathrm{C}$ and $90^{\circ} \mathrm{C}$ pectin's. However $90^{\circ} \mathrm{c}$ was higher $(P \leq 0.05)$ than that of $80^{\circ} \mathrm{C}$ extracted pectin.

\section{Total Anhydrouronic acid}

Total anhydrouronic acid (AUA) indicates the purity of extracted pectin (Tables 4,5 and Fig 5) showed the AUA content of pectin from orange peel using hydrochloric acid and citric acid at temperature 80 and $90^{\circ} \mathrm{C}$. According to Hydrochloric acid the AUA was found to be $44.74 \%$ and $61.96 \%$ respectively which was against $74.60 \%$ for commercial pectin. While citric acid, the AUA content of pectin was found to be $51.24 \%$ and $60.65 \%$ respectively. Devi et al., (2014) reported that AUA content of pectin of sweet lemon pomace extracted by citric and nitric was $51.52 \%$ and 51.04 $\%$ respectively. The AUA content indicates the purity of the extracted pectin and its value should not be less than $65 \%$ (Food Chemical Codex, 1996). Siti et al., (2020) reported that AUA content of pectin extracted from honey dew peel was $63.20 \pm 3.1 \%$ and $33.33 \pm 0.8$ 
Hager A. A. Rahma, et al.,

using citric and nitric acid respectively at $80^{\circ} \mathrm{c}$ for $60 \mathrm{~min}$. The percentage of AUA obtained in this study (Table 5) do not accept for minimum limits of pectin purity since the value must be greater than $65 \%$. The lower value of AUA indicates that the isolated pectin might have a high amount of protein content, starch and sugars that existed in the pectin precipitate (Ismail et al., 2012). This is true because the pectin isolated at $80^{\circ} \mathrm{C}$ was higher in protein and ash content than that of $90^{\circ} \mathrm{C}$ extraction (Table 4 and Fig 5) therefore our isolated pectin requires further purification to increase its purity. The ANOVA tests showed that the temperature had a significant effect on AUA content of pectin which there was a significant $(P \leq 0.05)$ difference between the two isolated pectin samples.

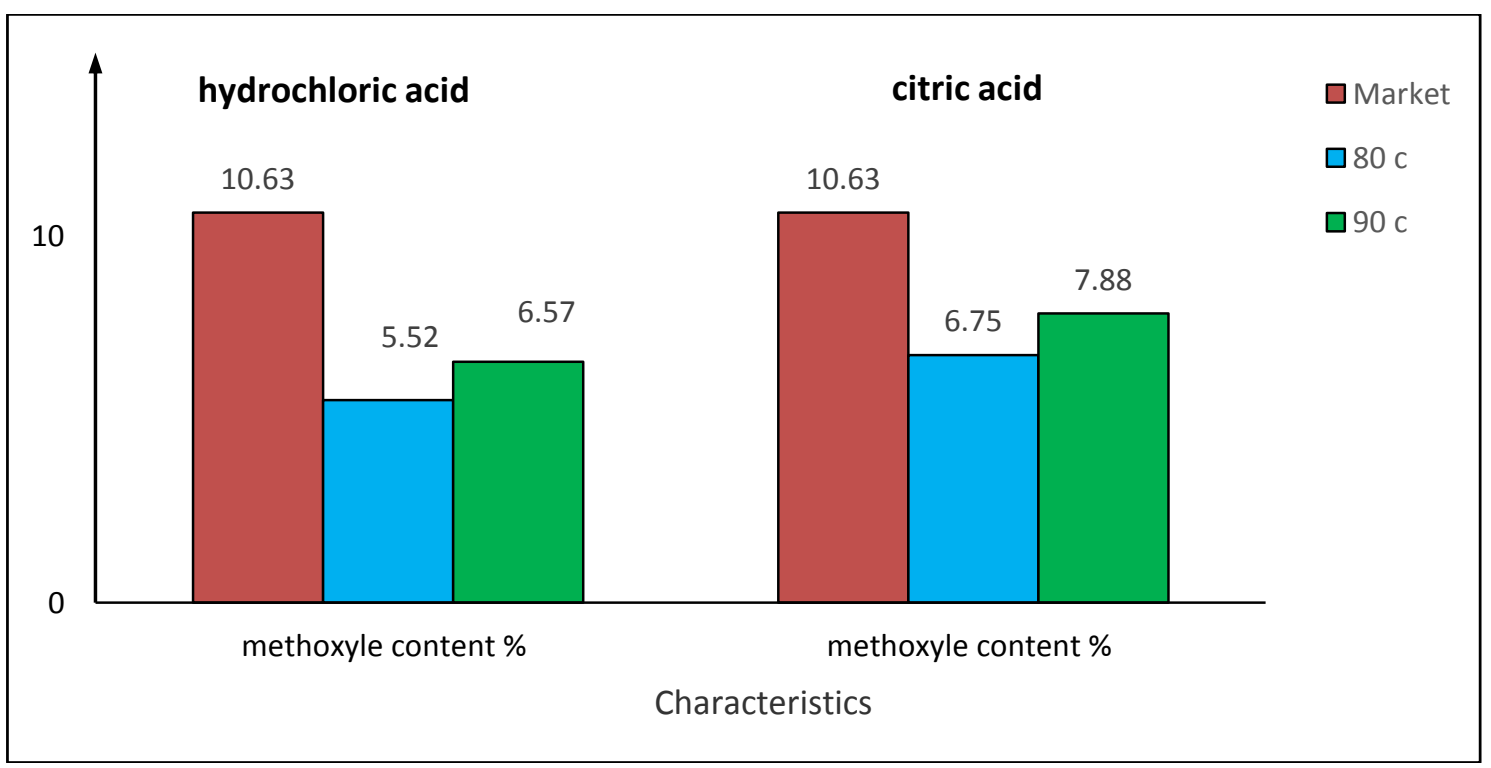

Figure (4): Methoxyle content of orange peel pectin extracted by hydrochloric acid and citric acid at different temperature

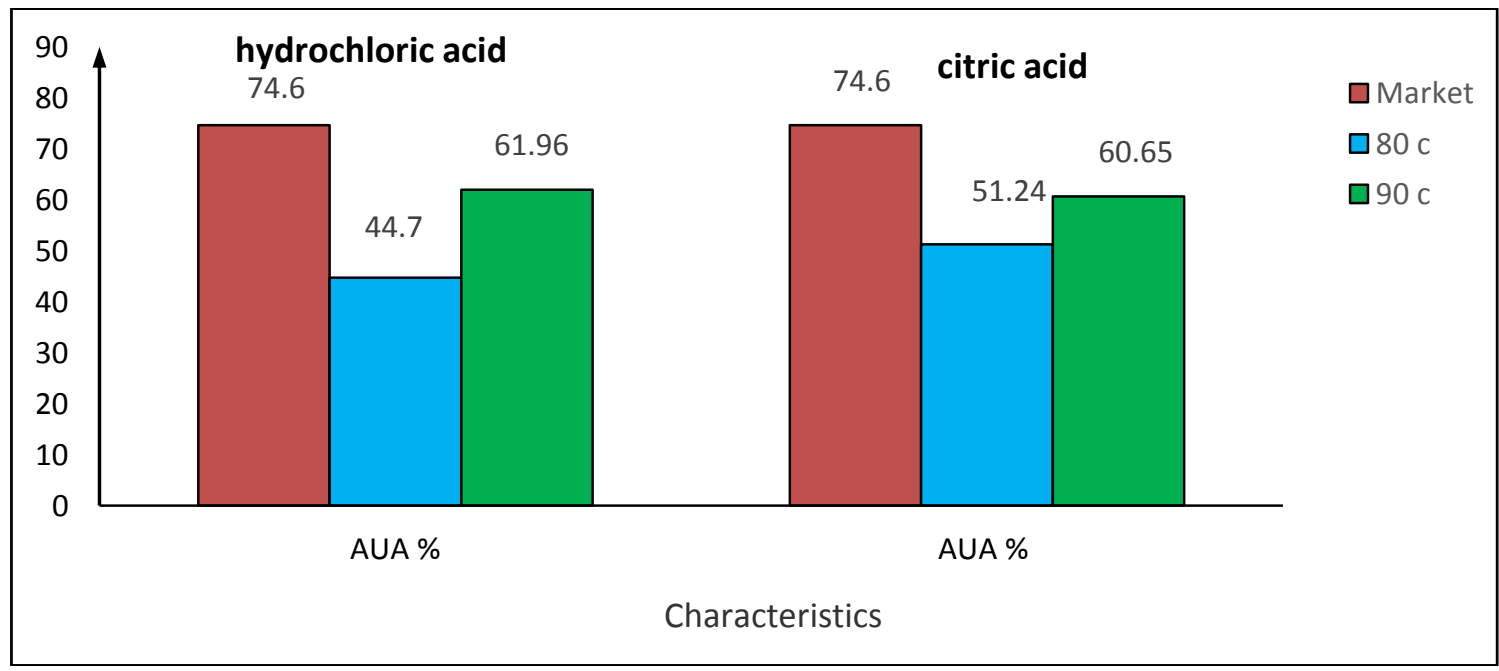

Figure (5): Total Anhydrouronic acid of orange peel pectin extracted by hydrochloric acid and citric acid at different temperature 


\section{Degree of esterification}

Degree of esterification of orange peels extracted by hydrochloric acid $0.3 \mathrm{~N}$ at $80^{\circ} \mathrm{C}$ and $90^{\circ} \mathrm{C}$ for $60 \mathrm{~min}$ which was found to be $76.56 \%$ and $76.18 \%$ respectively (Table 4 and Fig 6) which is against $89.37 \%$ for market pectin. While the degree of esterification of orange peel extracted pectin by citric acid was found to be $81.37 \%$ and $82.10 \%$ respectively (Table 5 and Fig 6). Siti et al., (2020) reported that the DE was affected by acid used for extraction, citric acid showed a low degree of esterification $(50.38 \pm 1.36 \%)$ compared to that of nitric acid extracted pectin $(59.88 \pm 1.39 \%)$ for honeydew peel pectin. The values of degree of esterification of this work were higher than those reported by Rose and Abilasha, (2016) for lemon peel using nitric acid $\mathbf{2 0 . 0 7 \%}$. Based on our results which indicate that the orange peel extraction of pectin at $80^{\circ} \mathrm{C}$ and $90^{\circ} \mathrm{C}$ using hydrochloric acid and citric acid are recognized as high methoxyle pectin because its DE is more than $50 \%$. High methoxyle pectin can form gel with the presence of sugar and acid which is called sugar acid pectin gel. The ANOVA testes showed that the temperature had no significant $(P>0.05)$ effect on $D E$ of both extracted pectin.

\section{Moisture content}

Moisture content of pectin extracted from orange peel using hydrochloric acid $0.3 \mathrm{~N}$ at $80^{\circ} \mathrm{C}$ was found to be $7.47 \%$ and $8.93 \%$ respectively (Table 4 and Fig 7) which is against $9.56 \%$ for commercial pectin. While the moisture content of pectin extracted from orange peel using citric acid was found to be $6.6 \%$ and $8.63 \%$ respectively (Table 5 and Fig 7 ). It is necessary to keep in mind that high moisture content could enhance the growth of microorganisms and production of pectinase enzymes that can further affect the pectin quality (Muhamadzadeh et al., 2010). The pectin is very hygroscopic. For this reason it must be preserved in closed dry conditions. Statistical analysis showed significant difference between market sample and extracted pectin at $80^{\circ} \mathrm{C}$ and $90^{\circ} \mathrm{C}$.

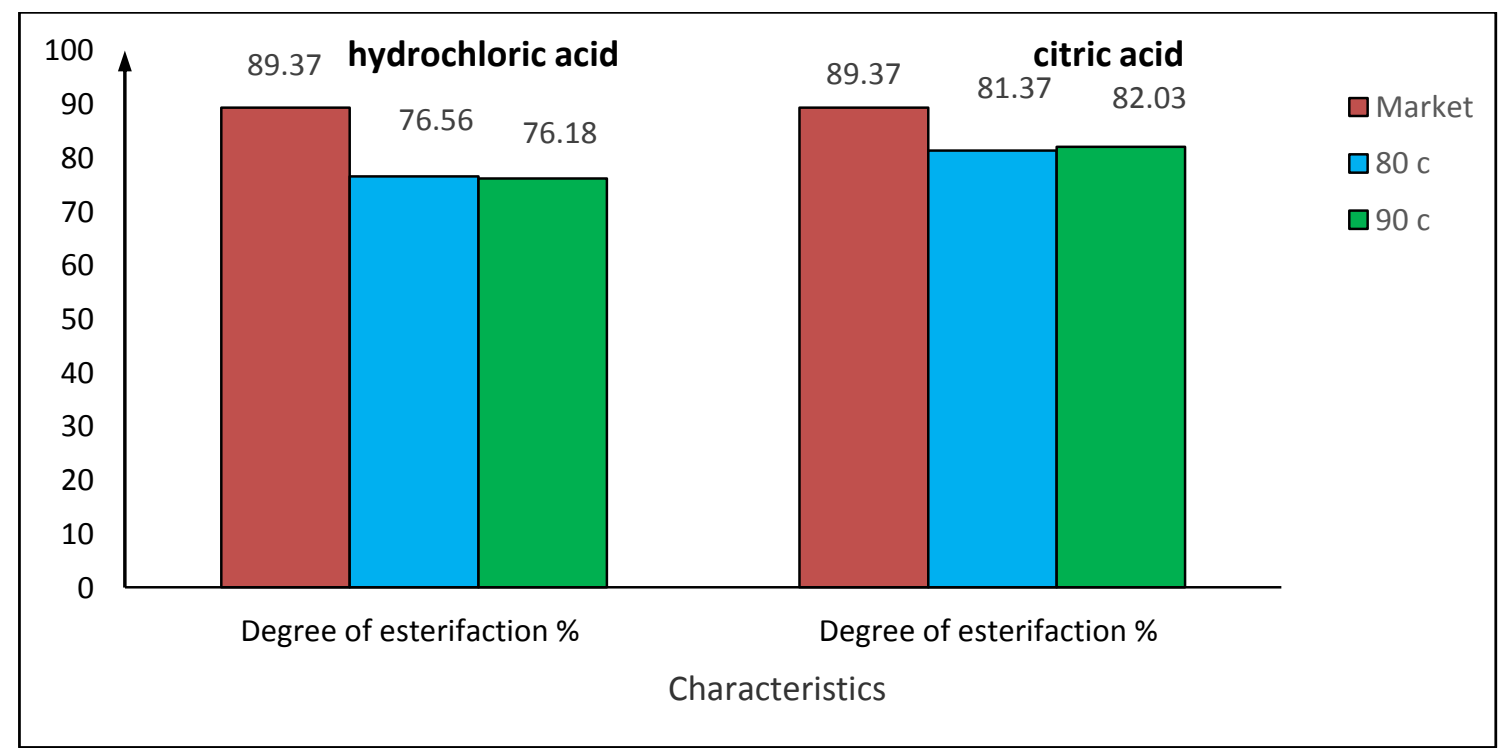

Figure (6): Degree of esterification of orange peel pectin extracted by hydrochloric acid and citric acid at different temperature 
Hager A. A. Rahma, et al.,

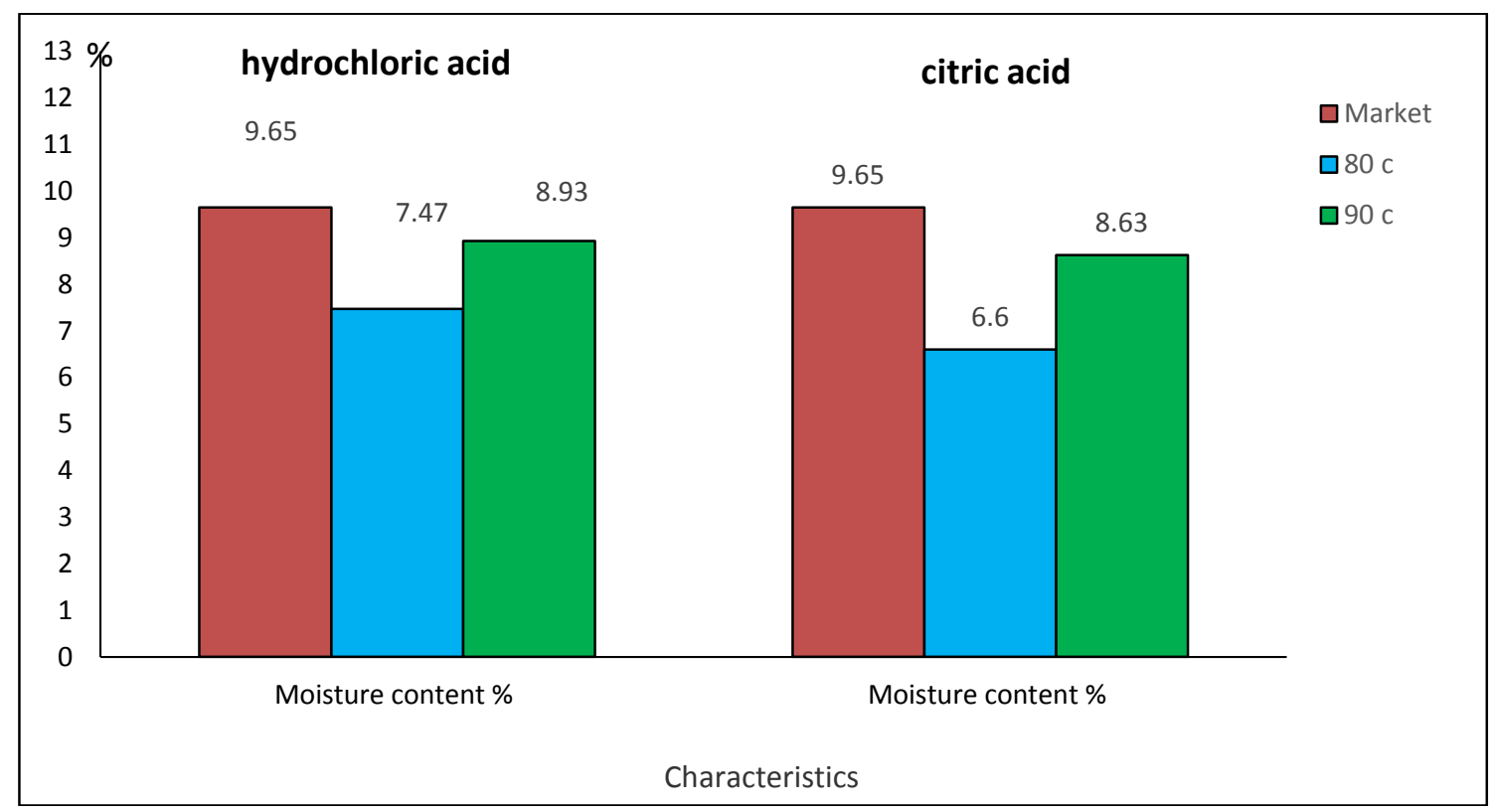

Figure (7): Moisture content of orange peel pectin extracted by hydrochloric acid and citric acid at different temperature

\section{Ash content}

Ash content of pectin extracted from orange peels using hydrochloric acid $0.3 \mathrm{~N}$ at $80^{\circ} \mathrm{C}$ and $90^{\circ} \mathrm{C}$ was found to be $5.40 \%$ and 4.39 respectively which is against 2.91 for commercial pectin (Table 4 and Fig 8). While Ash content of pectin extracted from orange peel using citric acid was found to be $4.03 \%$ and $3.78 \%$ respectively (Table 5 and Fig 8). (Hamed et al., 2017) reported that ash content of pumpkin peel pectin extracted using nitric and citric was 3.17 \%and $2.96 \%$ respectively. (Azad et al., 2014) reported that ash content below $10 \%$ is one of the good indicators for gel formation. Therefor the ash content found in our pectin samples indicated its purity and good quality of both samples. The Ash content of isolated pectin was much higher than market samples which contain $2.19 \%$. Statistical analysis showed that temperature had a significant $(P \leq 0.05)$ effect on ash content of pectin extracted using hydrochloric acid $0.3 \mathrm{~N}$.

\section{Protein content}

Protein content of the extracted pectin from orange peels using $0.3 \mathrm{~N}$ at temperature $80^{\circ} \mathrm{C}$ and $90^{\circ} \mathrm{C}$ was found to be $6.40 \%$ and $5.57 \%$ which is against $2.71 \%$ for commercial pectin (Table 4 and Fig 9). While the protein content of the extracted pectin from orange peel was found to be $7.3 \%$ and $6.18 \%$ at $80^{\circ} \mathrm{c}$ and $90^{\circ} \mathrm{C}$ respectively (Table 5 and Fig 9 ). The low protein content for $90^{\circ} \mathrm{C}$ isolated pectin could be due to the effect of heat during extraction and removing more protein compared to $80^{\circ} \mathrm{C}$. High protein content may affect the colour of pectin and gel quality properties. ANOVA testes showed that temperature had a significant $(P \leq 0.05)$ effect on protein content of pectin. 


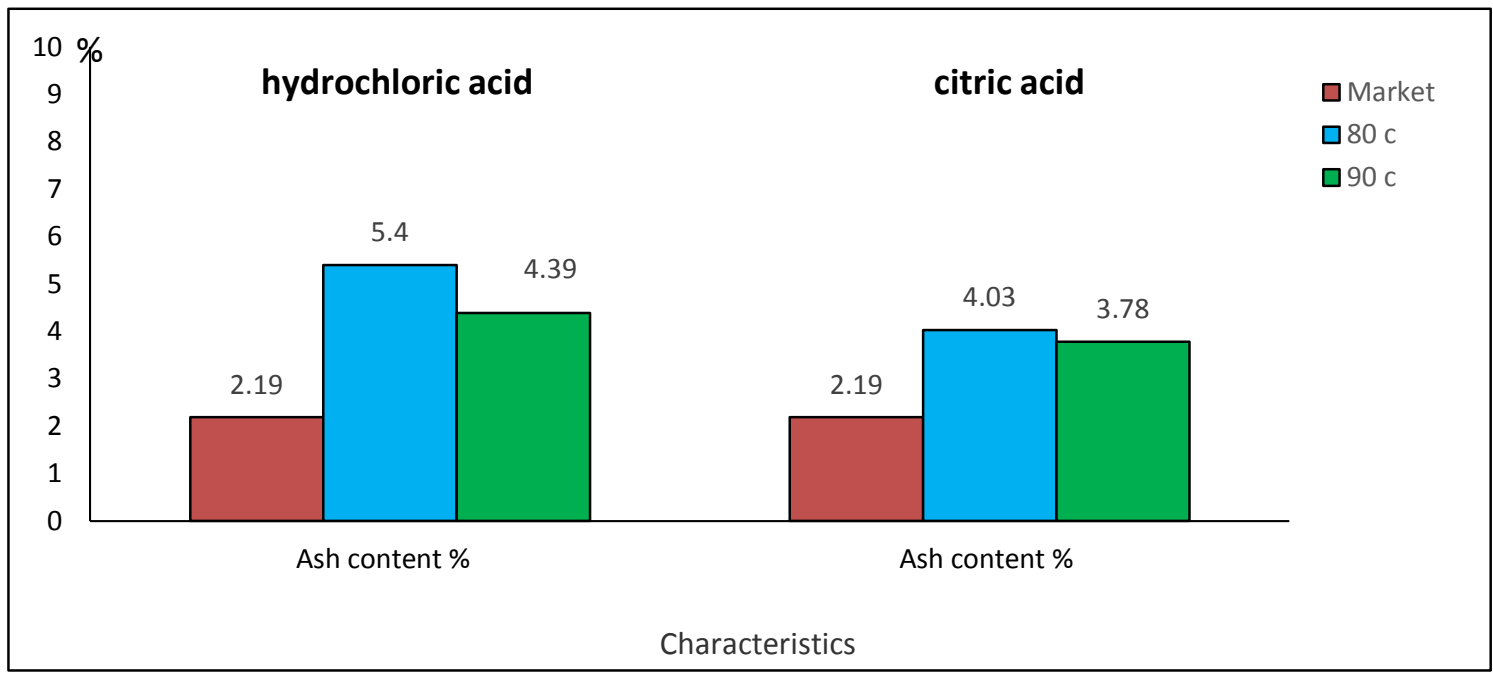

Figure (8): Ash content of orange peel pectin extracted by hydrochloric acid and citric acid at different temperatures

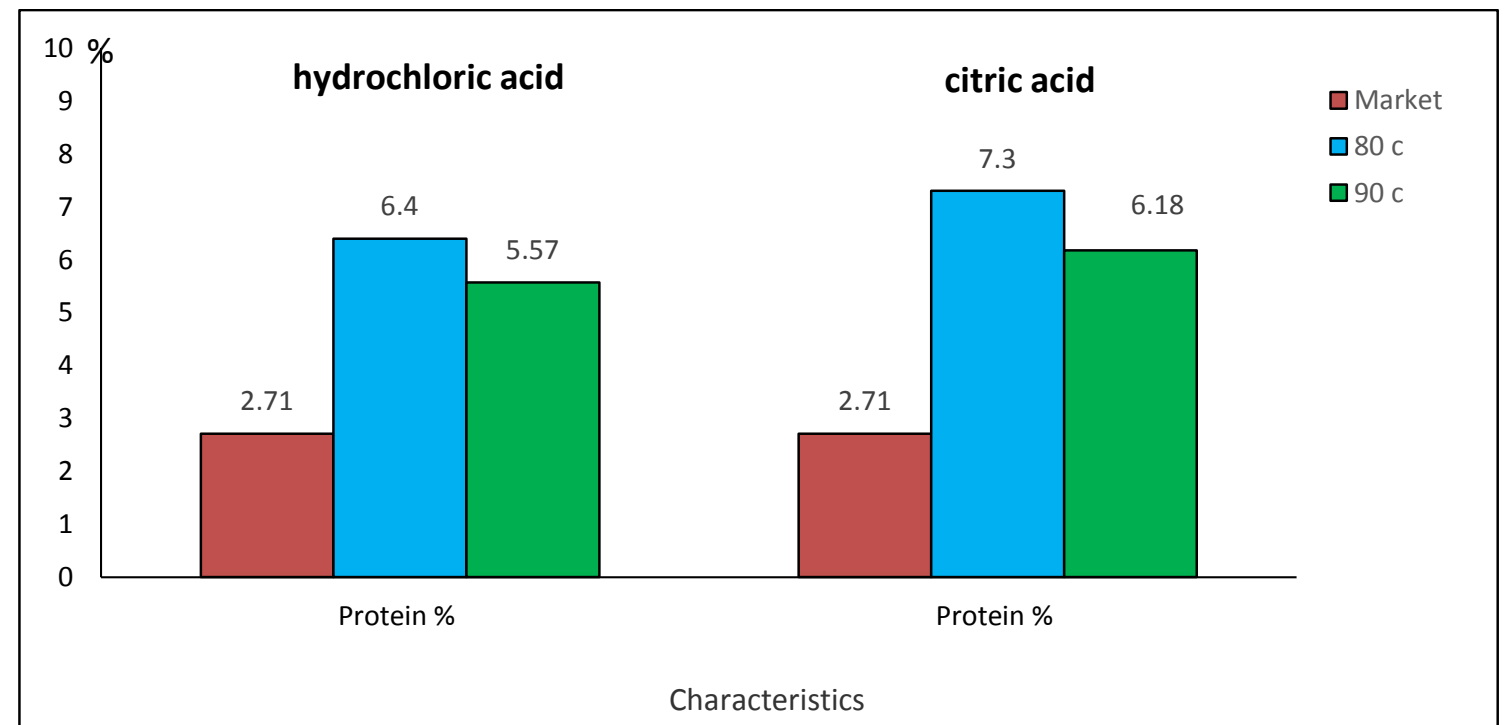

Figure (9): Protein content of orange peel pectin extracted by hydrochloric acid and citric acid at different temperature

\section{Conclusion}

This study emphasized the extraction and characterization of pectin from orange peels. From the obtained results it is shown that citric acid produced higher yield of pectin $\mathbf{5 4 . 8 0} \%$ compared to $\mathrm{Hcl} 23.44 \%$. The optimum condition for pectin extraction was found to be the combination treatment of $90^{\circ} \mathrm{C}$ and 60 minutes of extraction. All the characteristics of the pectin are significantly affected by the types of acid used during the treatment. Temperature had a significantly effect on some physio-chemical such as $\mathrm{EW}, \mathrm{MeO}$ and AUA but the temperature hadn't effected on DE . Pectin obtained in this study was characterized as high methoxyl pectin (HMP) since the DE was higher than 50.AUA of isolated pectin by citric and $\mathrm{Hcl}$ was lower than $65 \%$ so the isolated pectin need for more purification. Also orange peels represent a good and cheap raw material for pectin production. 


\section{REFERENCES}

Altaf, U., G. Immanuel and F. Iftikhar (2014). Extraction and characterization of pectin derived from papaya (Carica papaya Linn) peel. International Journal of Science, Engineering and Technology. 4: 2348-4098

A.O.A.C., (1995). Official methods of analysis, 16th Ed. Association of Official Analytical Chemists, Washington, pp. 1-10

A.O.A.C. (1999). Association of official Analytical chemists. 16th ed, Association of Official Analytical Chemists, Maryland.

Azad, A., M. Ali, M. S. Akter, M. J. Rahman and M. Ahmed (2014). Isolation and characterization of pectin extracted from lemon pomace during ripening Journal of Food and Nutrition Sciences.2:30-35.

Constenla, D. and J. E. Lozano (2003). Kinetic model of pectin demethylation. Latin American Applied Research, 33: 91-96.

Cristina, M., R. Marina, J. Alfonso and C.G. Maria (2020). Recent Trends in the Use of Pectin from Agro-Waste Residues as aNatural -Based Biopolymer for Food Packaging Applications. journal materials. 13(3): 673

Devi, W.E., R.N. Shukla, K.L. Bala, A. Kumar, A.A. Mishra and K.C. Yadav (2014). Extraction of Pectin from Citrus Fruit Peel and Its Utilization in Preparation of Jelly. International Journal of Engineering Research \& Technology. 3(5): 1925-1932.

Food Chemical Codex. IV monographs. (1996). Washington DC: National Academy Press. p. 283.

Girma, E. and M.T. Worku (2016). Extraction and characterization of pectin from selected fruit peel waste. International Journal of
Scientific and Research Publications. 6(2): 447-454.

Hamed, A., A. Elkhedir and S. Mustafa (2017). Effect of Soxhlet method extraction on characterization of pectin of pumpkin peels. Journal of Experimental Food Chemistry.3(1): 1-3

Ismail, N.S.M., N. Ramli, N.M. Hani and Z. Meon (2012). Extraction and characterization of pectin from dragon fruit (Hylocereus polyrhizus) using various extraction conditions. Sains Malaysiana, 41: 41-45.

Kalapathy, U. and A. Proctor (2001). Effect of acid extraction of pectins from plant material by different $\mathrm{pH}$. Carbohydrate Polymer, 43: 62-69

Madhav, A. and P.B. Pushpalatha (2002). Characterization of pectin extracted from different fruit wastes. Journal of Tropical Agriculture. 40: 53-55.

Mohamed, S. and Z. Hasan (1995). Extraction and characterization of pectin from various tropical agrowastes. ASEAN Food Journal, 2: 43-50

Muhamadzadeh, J., A.R. SadghiMahoonak, M. Yaghbani and M. Aalam (2010). Extraction of Pectin from Sunflower Head Residues of Selected Iranian Caltivers. World Applied Science Journal, 8: 21-24.

Owens, H.S., R.M. McCready, A.D. Shepard, T.H. Schultz, E.L. Pippen, H.A. Swenson, J.C. Miers, R.F. Erlandsen and W.D. Maclay (1952). Methods used at Western Regional Research Laboratory for extraction of pectic materials. USDA Bur Agric Ind Chem, p. 9.

Ramli, N. and Asmawati (2011). Effect of ammonium oxalate and acetic acid at several extraction time and $\mathrm{pH}$ on some physicochemical properties of pectin from. cocoa husk (Theobroma cacao). African J Food Sci 5: 790-798. 
Ranganna, S. (1995). Hand book of analysis and quality control for fruits and vegetable products (2nd Ed.). New Delhi: McGraw Hill publishing Co. Ltd. pp. 33-43.

Rose, P.A.E. and D. Abilasha (2016). Extraction and characterization of pectin from lemon peel. International Journal of Advanced Science and Research. (1): 12-15.

Sharma, B.R., L. Naresh, N.C. Dhuldhoya, S.U. Merchant and U.C. Merchant (2006). An Overview on Pectins. Times. food processing journal 44-54.

Siti., R.O., A.M.H. Nurul and N.A. Muhammad (2020). Waste to wealth: optimizing novel pectin acid extraction from honeydew (cucumis melo $I$. var. inodorous) peels as a potential halal food thickener. MOJ Food Processing \& Technology 8; 1217

Snedecor, G. W. and W. G. Cochran (1994). Statistical methods (8th ed.). Calcutta, India: Oxford \& IBH Publishing Co.

Tsoga, A., R.K. Richardson and E.R. Morris (2004a). Role of cosolutes in gelation of highmethoxyl pectin. Comparison of sugars and polyols. Food Hydrocoll. 18: 907-919

Van Buren, J.P. (1991). Function of pectin in plant tissue structure and firmness. In The chemistry and technology of pectin. Academic Press. California.

Vauquelin, M. (1790). Analyse de tamarin. Ann. Chim. (Paris), 5: 92. 
Hager A. A. Rahma, et al.,

تأثثر وسط الإستخلاص والحمض علي الخواص الفيزيوكيميائية للبكتين المعزول من قثشور البرتقال

هاجر علي، السيد حلمي رحمه، طارق احمد العدوي، علاء الدين السيد البلتاجي

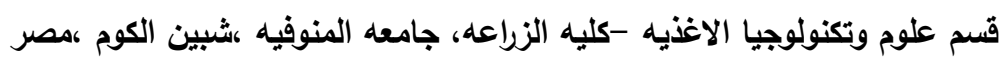

الملخص العربى

اجريت هذه الاراسه علي قثور البرتقال كمواد خام لانتاج البكتين وتم دراسه تأثير وسط الاستخلاص علي الخواص

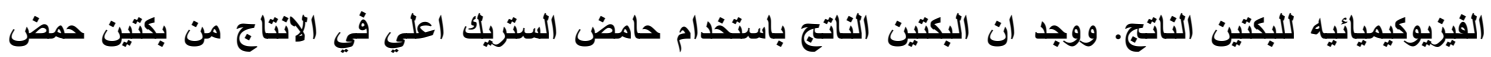
الهيروكلوريك 54.80 \% ، 23.44\% علي التوالي وكان اعلي انتاج عند تركيز 1 عياري بالنسبه لحمض الستريك و0.3 عياري بالنسبه لحض الهيدروكلوريك وزمن الاستخلاص كان 60 دقيقه ودرجه الحراره 60 م في كل من حامض الستريك والهيدروكلوريك. وجد ان نوع الحامض له تأثير كبير علي الخواص الفيزيوكيميائيه للبكتين. وجد ايضا ان درجه

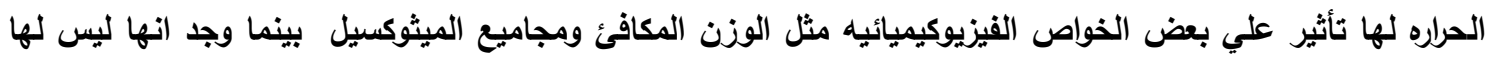
تأثير علي درجه الاستره .والبكتين المتحصل عليه في هذا البحث يندرج تحت بكتين مرتفع الميثوكسيل حيث ان اندئ درجه الاستره اعلي من 50\% ولكن وجد ان اجمالي حمض الانهيلرونك اقل من 65\% اي ان البكتين الناتج يحتاج الي مزيد من التنقيه وفي العموم فان النتائج اثتتت ان بكتين حمض الستريك له خواص فيزيوكيميائيه جيده، وهذه الاراسه اجريت لاراسه العوامل التي تؤُثر علي استخلاص البكتين وكذلك خواصه باستخدام قشور البرتقال كمواد خام .

أسماء السادة المحكمين

أ.د/ عادل السيد مبارك رئيس جامعة المنوفية

أ.د/ على حسن خليـل كلية الزراعة - جامعة المنوفية 